\title{
LIVESTOCK PRODUCTION - PRESENT SITUATION AND FUTURE DEVELOPMENT DIRECTIONS IN REPUBLIC OF SERBIA
}

\author{
S. Aleksić, V. Pantelić, Č. Radović \\ Institute for Animal Husbandry, 11080, Belgrade-Zemun, Republic of Serbia \\ Corresponding author: saleksic@mail.com \\ Invited paper
}

Abstract: Livestock production is important branch of agriculture in Republic of Serbia. Over 700.000 households are engaged in this production, which is over $55 \%$ of total number of households. Livestock production provides necessary products (milk, meat, eggs) for nutrition of domestic population. Also, livestock production provides raw materials for food industry (dairy plants, slaughterhouses, meat industry, conditory industry and leather industry). Livestock production is expected to provide high quality products for export, primarily beef and lamb meat. Chance/opportunity for export exists also for cheeses of high quality (especially sheep and goat cheeses) of defined origin and quality. Based on available data, current situation in livestock production is assessed as inviolable. Number of heads of all species of domestic animals and poultry has been constantly decreasing over the period of last 12 years. The greatest decrease of number of heads of livestock was recorded in years 2000, 2001 and 2002, in all species of domestic animals. During this period, number of cattle decreased by $18,6 \%$, of pigs by $11,8 \%$, sheep by $12,3 \%$, number of goats by $54,1 \%$, horses by $66,0 \%$ and poultry by $28,0 \%$. So, by the end of 2007 , number of cattle was 1.087.000, pigs 3.832.000, sheep 1.606.000, goats 149.000 , horses 18.000 and poultry 16.422.000. Republic of Serbia will in its near future become member of European Union (EU) and World Trade Organization (WTO), which means that livestock production should prepare for competition on unique developed market, without any state trade barriers. Serbia has been preparing for this since 2006 when it signed bilateral agreement on free trade with neighbouring countries - Central European Free Trade Agreement (CEFTA) and in this way became part of the market and accepted the competition rules on the free market. Accession to EU and WTO includes liberalization of trade in livestock products, low possibility for import protection, implementation of quality standards (HACCP; ISO, Global GAP), reduction of the level of domestic support, discontinuing of export subsidies, increase of profitability and ability to be competitive on the international market.

Key words: livestock production, number of livestock and poultry, breeds, production of livestock products, international market 


\section{Introduction}

Animal husbandry, together with crop farming, is the major branch of agriculture. Harmonious relationship and coordinated development of these two branches is a prerequisite for developing agriculture and successful accomplishing of tasks relating to human nutrition, development of processing industry and export of agricultural products. Serbia has considerable nature resources (agricultural land, climate, water and vegetable etc.) and very significant capacities and potentials (farmers, livestock fund, production and processing structures and techniques, etc.).

The Republic of Serbia has 5.1 million ha of agricultural land, 4.2 million ha of arable land and fields and 0.83 million ha grassland, approx. 0.6 ha of agricultural and 0.5 ha of arable land per capita. The quality of soil is best in low lands and moderately good in hilly and mountain regions.

Over 700.000 households are engaged in livestock production, which is over $55 \%$ of total number of households, and it is important branch of economy which participates in the gross domestic product with $42 \%$. Livestock production provides necessary products (milk, meat, eggs) for nutrition of domestic population. Also, livestock production provides raw materials for food industry (dairy plants, slaughterhouses, meat industry, conditory industry and leather industry). Livestock production is expected to provide high quality products for export, primarily beef and lamb meat. Chance/opportunity for export exists also for cheeses of high quality (especially sheep and goat cheeses) of defined origin and quality.

\section{Present situation in livestock production in Serbia}

In Table 1. data are presented relating to number of heads of domestic animals according to species in the period of last 12 years (Republic Bureau of statistics, 1996-2007).

Based on available data, current situation in livestock production is assessed as inviolable. Number of heads of all species of domestic animals and poultry has been constantly decreasing over the period of last 12 years. The greatest decrease of number of heads of livestock was recorded in years 2000, 2001 and 2002, in all species of domestic animals. During this period, number of cattle decreased by $18,6 \%$, of pigs by $11,8 \%$, sheep by $12,3 \%$, number of goats by $54,1 \%$, horses by $66,0 \%$ and poultry by $28,0 \%$. So, by the end of 2007 , number of cattle was 1.087 .000 , pigs 3.832 .000 , sheep 1.606 .000 , goats 149.000 , horses 18.000 and poultry 16.422 .000 . 
Table 1. Number of livestock and poultry in Serbia in last 12 years in 000

\begin{tabular}{|c|c|c|c|c|c|c|c|c|c|c|c|c|}
\hline Year & Cattle & Index & Pigs & Index & Sheep & Index & Goats & Index & Horses & Index & Poultry & Index \\
\hline 1996 & 1335 & 100.0 & 4344 & 100.0 & 1832 & 100.0 & 262 & 100.0 & 53 & 100.0 & 22806 & 100.0 \\
\hline 1997 & 1318 & 98.7 & 4119 & 94.8 & 1758 & 96.0 & 244 & 93.1 & 52 & 98.1 & 22365 & 98.1 \\
\hline 1998 & 1280 & 95.9 & 4057 & 93.4 & 1645 & 89.8 & 261 & 99.6 & 51 & 96.2 & 22599 & 99.0 \\
\hline 1999 & 1283 & 96.1 & 4293 & 98.8 & 1598 & 87.2 & 270 & 103.0 & 43 & 81.1 & 23278 & 102.0 \\
\hline 2000 & 1246 & 93.3 & 4066 & 93.6 & 1611 & 87.9 & 183 & 69.8 & 37 & 69.8 & 20360 & 89.3 \\
\hline 2001 & 1162 & 87.0 & 3615 & 83.2 & 1490 & 81.3 & 180 & 68.7 & 30 & 56.6 & 19290 & 84.6 \\
\hline 2002 & 1128 & 84.5 & 3587 & 82.6 & 1448 & 79.0 & 164 & 62.6 & 29 & 54.7 & 18804 & 82.4 \\
\hline 2003 & 1112 & 83.3 & 3634 & 82.6 & 1516 & 82.7 & 169 & 64.5 & 24 & 45.3 & 17676 & 77.5 \\
\hline 2004 & 1102 & 82.5 & 3439 & 79.2 & 1586 & 86.6 & 155 & 59.1 & 26 & 49.1 & 16280 & 71.4 \\
\hline 2005 & 1079 & 80.8 & 3165 & 72.9 & 1576 & 86.0 & 152 & 58.0 & 25 & 47.2 & 16631 & 72.9 \\
\hline 2006 & 1106 & 82.8 & 3999 & 92.1 & 1556 & 84.9 & 139 & 53.0 & 20 & 37.7 & 16595 & 72.8 \\
\hline 2007 & 1087 & 81.4 & 3832 & 88.2 & 1606 & 87.7 & 149 & 56.9 & 18 & 34.0 & 16422 & 72.0 \\
\hline
\end{tabular}

No better is the situation in regard to number of breeding animals (Table 2). In the period from 2001 to 2007 number of cows and pregnant heifers has decreased by $12,7 \%$.

Table 2. Number of livestock and poultry per species and categories in Serbia in 000

\begin{tabular}{|l|c|c|c|c|c|c|}
\hline $\begin{array}{l}\text { Species and } \\
\text { categories }\end{array}$ & $\begin{array}{l}2001 \\
\text { year }\end{array}$ & Index & $\begin{array}{c}2003 \\
\text { year }\end{array}$ & $\begin{array}{c}2005 \\
\text { year }\end{array}$ & $\begin{array}{l}2007 \\
\text { year }\end{array}$ & Index \\
\hline Cattle \\
\hline $\begin{array}{l}\text { Cows and heifers in } \\
\text { calf }\end{array}$ & 787 & 100 & 740 & 721 & 648 & 82.3 \\
\hline Pigs & 700 & 825 & 654 & 550 & 69.6 \\
\hline $\begin{array}{l}\text { Sows and sows of first } \\
\text { farrow }\end{array}$ & 790 & 100 & 44 & 30 & 25 & 67.6 \\
\hline Boars for service & 37 & 100 & & & \\
\hline Sheep & 1186 & 100 & 1133 & 1169 & 1192 & 100.5 \\
\hline Ewes for breeding &
\end{tabular}

In regard to number of sows and pregnant gilts decrease is even greater by $30,4 \%$, whereas the number of breeding sheep remained at the same level. It should be pointed out that number of cows and pregnant heifers of 648000 heads at the end of 2007 can have significant effect on future development of cattle production. Because of relatively long production cycle it will take longer for this production to be restored. In pig production, the greatest decrease was registered in number of sows and pregnant gilts $(30,4 \%)$. This will surely have deleterious 
impact on future development of this production. Although the number of breeding sheep has not decreased, total situation in sheep breeding is unsatisfactory since not all present potentials for increase of number and quality of breeding animals had been exploited.

Production of milk in Serbia is one of the major livestock production in regard to number of agricultural households engaged in this production as well as in value of this production which is additionally increased (added value) by processing of milk into dairy products. Production of milk, in spite of decrease of number of heads, is constant and at the same level since year 2000 (Table 3). This can be explained by increased production of milk per cow. Genetic progress in milk traits was achieved by use of progeny tested bulls and increase of use of artificial insemination of cows and heifers and through import of high quality pregnant heifers (Aleksić et al., 2007).

Table 3. Production of milk, eggs and wool in Serbia

\begin{tabular}{|c|c|c|c|c|c|c|c|c|}
\hline \multirow[b]{2}{*}{ Year } & \multicolumn{4}{|c|}{ Milk in million litres } & \multirow{2}{*}{$\begin{array}{l}\text { Hen } \\
\text { eggs in } \\
\text { mill. }\end{array}$} & \multirow[b]{2}{*}{ Index } & \multirow{2}{*}{$\begin{array}{l}\text { Wool } \\
\text { tons }\end{array}$} & \multirow[b]{2}{*}{ Index } \\
\hline & $\begin{array}{c}\text { Cow's } \\
\text { milk }\end{array}$ & Index & $\begin{array}{c}\text { Sheep } \\
\text { milk }\end{array}$ & Index & & & & \\
\hline 2000 & 1566 & & 19 & & 1374 & & 2264 & \\
\hline 2003 & 1576 & 100.0 & 13 & 100.0 & 1421 & 100.0 & 2322 & 100.0 \\
\hline 2005 & 1602 & 101.6 & 14 & 107.7 & 1476 & 103.9 & 2527 & 108.8 \\
\hline 2006 & 1587 & 100.7 & 15 & 115.4 & 1456 & 102.5 & 2493 & 107.4 \\
\hline 2007 & 1549 & 98.3 & 14 & 107.7 & 1364 & 96.0 & 2499 & 107.6 \\
\hline
\end{tabular}

Data in Table 3. indicate the decrease in production of cow milk whereas production of sheep milk increased. Production of eggs in observed period was relatively stable. Because of the import of genetic material, protein feeds, additives and medicines, this production is to great extent import dependant.

Drastic decrease of number of livestock in the period from 1996 to 2001 of all species of domestic animals has reflected on decrease in production of meat. As orientation for production results year 2003 was taken when number of domestic animals had stabilized. Since 2003, total meat production increases $(10 \%)$, but insufficiently from the aspect of existing capacities and potential export opportunities (Table 4). Export of beef was in expansion until Italy (1974) and Greece (1980) became members of the European Economical Community. For instance, in 1974, 50.500t/year was exported to Italy, and in $198051.310 \mathrm{t}$ (Aleksić et al., 2005; Aleksić et al., 2007). 
Table 4. Production of meat in Serbia in 000 tons

\begin{tabular}{|l|c|c|c|c|c|c|c|c|c|c|}
\hline Year & Total & Index & $\begin{array}{c}\text { Beef } \\
\text { meat }\end{array}$ & Index & $\begin{array}{c}\text { Pork } \\
\text { meat }\end{array}$ & Index & $\begin{array}{c}\text { Sheep } \\
\text { meat }\end{array}$ & Index & $\begin{array}{c}\text { Poultr } \\
\text { y meat }\end{array}$ & Index \\
\hline 2000 & 518 & & 104 & & 283 & & 19 & & 67 & \\
\hline 2003 & 430 & 100 & 95 & 100 & 258 & 100 & 18 & 100 & 59 & 100 \\
\hline 2005 & 431 & 100,2 & 90 & 94,7 & 253 & 98,1 & 21 & 116,7 & 67 & 113,5 \\
\hline 2006 & 433 & 100,7 & 83 & 87,4 & 255 & 98,8 & 20 & 111,1 & 75 & 127,1 \\
\hline 2007 & 474 & 110,2 & 95 & 100,0 & 289 & 112,0 & 20 & 111,1 & 70 & 118,6 \\
\hline
\end{tabular}

Production of pork during observed period was increasing. Problem was that the structure of slaughtered pigs was not good. In total number of slaughtered pigs one third were piglets. Serbia has tradition in production and consumption of pork. Existing production of pork is sufficient to satisfy domestic needs and one part can be exported in form of durable products and cans.

Similar situation is in the production of mutton. Of total production of mutton approx. $70 \%$ is meat of young lambs at the age of 90 days. Considering that lamb meat represents strategic product, this production should be restored on private farms owned by individual agricultural producers.

Production of poultry meat is relatively stable. In Serbia, annually 65.000 tons of poultry meat is produced and mainly used for nutrition of domestic population. Because of short production cycle this production is easier for restoration and is less of a problem compared to other branches of livestock production (Cmiljanić et al., 2006).

\section{Breed composition}

Cattle breeding: Dominant breeds are Domestic Spotted and Simmental cattle, participating by about $70 \%$ in total number, then crossbreds of Domestic Spotted and Simmental and Busha cattle participating with about 25\%, and about $5 \%$ are Black and Red-White cattle of European White-Black and Holstein breeds.

Sheep breeding: Sheep breed composition is unfavourable since $80 \%$ of animals belong to Pramenka, with most represented Pirot, Svrljig and Sjenica strains. Tzigai sheep participates with about $5 \%$, and $15 \%$ are crossbreds of Pramenka and imported foreign breeds, among which the most often is Württemberg sheep.

Goat breeding: Balkan goat living in low land regions is represented by about $40 \%$, and goat living in higher regions $15 \%$. The crossbreds between Balkan and other breeds make about 35\%, domestic Saanen goat 5\% and the Alpine and Saanen goat about 5\%.

Pig breeding: Among swine meat species the most often is Swedish Landrace and Great Yorkshire, while Dutch, German and Belgian Landrace. 
Domestic meaty pig, Hampshire, Duroc and Pietrain are present in a small number (less than $1 \%$ individually). Crossbreds from various combinations of crossbreeding are frequent, being in sows on larger farms about $60 \%$, where most frequent is the F1 generation between Great Yorkshire and Swedish Landrace. Private producers with small number of pigs most often grow crossbreds obtained by unplanned cross-breeding.

Poultry breeding: Market production of eggs and broilers is based on the hybrids of light and heavy types.

\section{Future directions of development of livestock production in Serbia}

Republic of Serbia will in its near future become member of European Union (EU) and World Trade Organization (WTO), which means that livestock production should prepare for competition on unique developed market, without any state trade barriers. Serbia has been preparing for this since 2006 when it signed bilateral agreement on free trade with neighbouring countries - Central European Free Trade Agreement (CEFTA) and in this way became part of the market and accepted the competition rules on the free market. Accession to EU and WTO includes liberalization of trade in livestock products, low possibility for import protection, implementation of quality standards (HACCP; ISO, Global GAP), reduction of the level of domestic support, discontinuing of export subsidies, increase of profitability and ability to be competitive on the international market.

Developed countries are already facing the trend of increased production of food, and at the same time population of consumers is decreasing which is reflected on the market by permanent decrease of prices. Based on existing situation in livestock production, as well as previous domestic and international practice, a quick and efficient transformation of livestock production is necessary in order to be competitive on the international market (Aleksić et al., 2005; Aleksić et al., 2007). Therefore, it is necessary first of all to stop further decrease of number of certain species of domestic animals.

It is necessary to improve the production potential of certain species and breeds of domestic animals using genetic-selection measures. Beside standard selection methods, today methods of molecular genetic are used more and more. All this knowledge should be used when developing breeding programs.

By application of new technologies in livestock production and processing a higher level of production and improved quality of livestock products will be ensured. By introduction of new technologies the efficiency and competitiveness of this production will be improved on the global market (Petrović et al., 2005). Future livestock production will be based on private farm production with market 
orientation. By specializing production higher profitability will be ensured, and in this way competitiveness on foreign market. It is necessary to associate market oriented producers into associations which would contribute to more rational utilization of available assets. Specialized farms for production of milk have objective to produce high quality milk which is in compliance with standards in regard to $\%$ of milk fat, $\%$ of milk proteins and especially bacteriological safety of milk. On specialized farms a system of certification and registration should be introduced since in this way the value of product is increased (Petrovic et al., 2002, 2003). Milk produced in this way can be validated on the market through special dairy products, promotion of brands and commercial - trade marks (hard cheeses, semi-hard cheeses, white cheeses, milk beverages, etc.). Also, specialized farms for production of meat have objective which is production for domestic needs and export. Future of Serbian export of meat is in production of young beef and lamb meat of such quality which is in compliance with demands of the adequate market. One of the ways for efficient improvement of production of high quality meat is crossing for the purpose of realization of better gain, carcass quality and meat quality (Čobić et al., 1990; Aleksić et al., 1998; Petrović et al., 2005).

In livestock production it is necessary to provide certain quality of products. This quality has to be monitored constantly using modern control methods (HACCP and GAP, etc. ). It is necessary to provide the principle of traceability, which means that certain product can be traced to the primary production, through processing to ultimate consumer. Adjustment/harmonization of regulations and practice to those which are implemented in EU, so called Acquis Communautaire is necessary, and if these standards are accepted export opportunities for livestock products will be greater

For improvement of livestock production in Serbia it is necessary to provide indispensable quantities of high quality livestock food (forage and concentrated). Food is one of the most important para-genetic factors in modern livestock production. By providing high quality feed we provide not only higher level of livestock production but also better quality of product (Cmiljanić et al., 2006).

Promotions and marketing are also important in realization of greater export of livestock products. For realization of greater export, besides incentives provided by government, it is necessary to have products which comply with standards of the global market. Greater export will have stimulation effect on improvement of livestock production in Serbia.

Measures of the agricultural policy should provide incentives to market oriented producers to produce more efficiently and to produce products of better quality. Credits for livestock producers under more favourable conditions (lower interest rates and longer grace period) also contribute to faster development of livestock production in Serbia. 
All afore mentioned measures should be long term because of the long production cycle in livestock breeding, since this is the only way to provide progress in livestock production.

\title{
Conclusion
}

Condition in livestock production was assessed as inviolable. Number of heads of all species of domestic animals is decreasing constantly. Decrease is especially noticeable and negative in female breeding animals used for reproduction (cows and pregnant heifers, sows and pregnant gilts and breeding sheep and goats). Consequence of decrease of number of livestock is decrease of production. This reflected especially in 2003 on production of certain meat types when significant decrease of this production was recorded. Contrary to production of meat, production of milk and eggs was relatively stable.

Long term implementation of recommended measures should stop further decrease of number of livestock, provide increase of profitability and competitiveness of livestock production and especially improve the quality of livestock products, which is especially important for export as crucial factor of future development of livestock production in Serbia.

\section{Acknowledgment}

Research was financed by the Ministry of Science and Technological Development of Republic of Serbia within project TR-20042.

\section{Stočarska proizvodnja - stanje i budući pravci razvoja u Republici Srbiji}

\author{
S. Aleksić, V. Pantelić, Č. Radović
}

\section{Rezime}

Stočarska proizvodnja je značajna grana poljoprivrede u Republici Srbiji. Zastupljeno je u preko 700.000 domaćinstava (55\% od ukupnog broja domaćinstava) i predstavlja značajnu privrednu granu koja učestvuje u formiranju društvenog proizvoda poljoprivrede sa $42 \%$. Stočarskom proizvodnjom se obezbeđuju neophodni proizvodi (mleko, meso, jaja) za ishranu domaćeg stanovništva. Pored toga stočarstvo obezbeđuje sirovine za prehrambenu industriju 
(mlekare, klanice, konditorske industrije i industrija prerade kože). Od stočarske proizvodnje se očekuje da obezbedi kvalitetne proizvode za izvoz, pre svega juneće i jagnjeće meso. Šansu za izvoz imaju i kvalitetni sirevi (posebno ovčiji i koziji) sa definisanim poreklom i kvalitetom.

$\mathrm{Na}$ osnovu raspoloživih podataka stanje stočarstva u Srbiji se ocenjuje kao nepovoljno. Broj grla kod svih vrsta domaćih životinja i živine u poslednjih dvanaest godina konstantno opada. Najveće smanjenje broja grla registrovano je u toku 2000., 2001., i 2002. godine kod svih vrsta domaćih životinja. U ovom periodu broj goveda je smanjen za $18,6 \%$, broj svinja za $11,8 \%$, broj ovaca za $12,3 \%$, broj koza za $54,1 \%$ broj konja za $66,0 \%$ i broj živine za $28,0 \%$. Tako da je na kraju 2007. godine broj grla goveda $1.087 .000,3.832 .000$ grla svinja, 1.606.000 grla ovaca, koza 149.000, 18.000 grla konja i 16.422 .000 živine.

Republika Srbija u bližoj budućnosti postaće član Evropske unije (EU) i Svetske trgovinske organizacije (STO) što znači da se stočarska proizvodnja mora pripremiti za konkurenciju na jedinstvenom razvijenom tržištu, na kome neće postojati državne trgovinske barijere. Srbija na tom putu se priprema već od 2006. godine potpisivanjem bilateralnog sporazuma o slobodnoj trgovini sa susednim zemljama (Central European Free Trade Agreement (CEFTA) i samim tim postala deo tržišta i prihvatila pravila konkurencije na slobodnom tržištu. Pristupanje u EU i STO podrazumeva veću liberalizaciju trgovine stočarskim proizvodima, mala mogućnost zaštite od uvoza, implementacija standarda kvaliteta (HACCP; ISO, Global GAP), smanjenje nivoa domaće podrške, ukidanje izvoznih subvencija, povećanje profitabilnosti i sposobnost da se izdrži konkurencija na međunarodnom tržištu.

\section{References}

ALEKSIĆ S., PETROVIĆ M.M., SRETENOVIĆ LJ., PANTELIĆ V., TOMAŠEVIĆ D. (2007): Cattle production - current situation and future direction in Republic of Serbia. Biotechnology in Animal Husbandry, Book 1, 23, 5-6, 1-11. ALEKSIĆ S., PETROVIĆ M.M., MIŠČEVIĆ B., PANTELIĆ V., TOMAŠEVIĆ D., OSTOJIĆ D. (2005): Proizvodnja kvalitetnog junećeg mesa u skladu sa evropskim trendovima. Biotechnology in Animal Husbandry, 21, 5-6,49-54.

ALEKSIĆ S., LAZAREVIĆ R., MIŠČEVIĆ B., PETROVIĆ M.M., JOSIPOVIĆ S. (1998): Fiksni uticaj genotipa na kvalitet junećeg mesa. Biotehnologija u stočarstvu, 1-2, 31-39.

ALEKSIĆ S., LAZAREVIĆ R., MIŠČEVIĆ B., PETROVIĆ M.M., JOSIPOVIĆ S. (1997): Nove tehnologije za povećanje prinosa i kvaliteta junećeg mesa domaće šarene rase namenjenog izvozu. Biotehnologija u stočarstvu, posebna edicija, 1724. 
ALEKSIĆ S., LAZAREVIĆ R., MIŠČEVIĆ B., PETROVIĆ M.M., JOSIPOVIĆ S. (1995): Proizvodni i ekonomski aspekti ukrštanja domaće šarene rase sa francuskim tovnim rasama. Tehnologija mesa 2-3, god. XXXVI, 77-79.

CMILJANIĆ R., PETROVIĆ M.M., PAVLOVSKI Z., TRENKOVSKI S., RADOVIĆ Č. (2006): Stanje stočarstva u Srbiji i budući pravci razvoja. Biotechnology in Animal Husbandry, 22, 5-15.

ČOBIĆ T., NENADOVIĆ M., MEDIĆ D., NOVAKOVIĆ M. (1990): Ispitivanje tovnih sposobnosti muških meleza $F_{1}$ generacije šaroleske i limuzinske sa simentalskom rasom goveda. Biotehnologija u stočarstvu, 3-4, 3-13.

PETROVIĆ M.M., BOGDANOVIĆ V., PETROVIĆ P.M., RUŽIĆ-MUSLIĆ D., OSTOJIĆ D. (2002): Mogućnosti unapređenja stočarstva brdsko-planinskog područja Srbije, Biotechnology in Animal Husbandry, 18, 5-6, 1-8.

PETROVIĆ M.M., LAZAREVIĆ LJ. (2003): The present situation in the livestock production in the Republic of Serbia and measures for its improvement. Biotechnology in Animal Husbandry, 19, 5-6, 13-23.

PETROVIĆ P.M., RUŽIĆ D., ŽUJOVIĆ M., SKALICKI Z. (2004): Perspektive Selekcije u ovčarstvu Srbije, Biotechnology in Animal Husbandry, 20, 5-6, 87-92. REPUBLIČKI ZAVOD ZA STATISTIKU SRBIJE (1996-2007). 